\title{
Report from the ASCB Education Committee
}

\section{Sarah Elgin}

\author{
Department of Biology, Washington University, St. Louis, Missouri 63130-4899
}

The Education Committee of the American Society for Cell Biology is delighted to participate in the launch of Cell Biology Education. We plan to provide a regular column with information on our plans and programs, soliciting your input and participation.

The Education Committee is one of the standing committees of the Society, as described in the Constitution and Bylaws. The Committee has undertaken a number of projects, sponsoring publications in cell biology such as the "Cellebrations" videotape edited by Rachel Fink, and the "Methods in Cell Biology" series edited by Leslie Wilson and Paul Matsudaira, published by Academic Press. We also sponsor publication of career information, for example "Exploring the cell: what cells do and how cell biologists study them," for high school students, as well as the "How to get Get a Job..." series for our younger members. Most recently, the Committee sponsored a study of education/workforce/career structure issues under the leadership of past chairman Frank Solomon. The results of this effort, funded by a grant from the Sloan Fondation, were published in Science (Freeman et al., 2001, "Competition and careers in biosciences," 294, 2293-2294); the complete report "Careers and rewards in bio sciences: the disconnect between scientific progress and career progression," by R.B. Freeman, E. Weinstein, E. Marincola, J. Rosenbaum, and F. Solomon, can be found on the ASCB web site at www.ascb.org/publications/competition.html.

The Education Committee sponsors a number of events at the ASCB Annual Meeting. These are designed to showcase some of the outstanding work that our members are doing in life science education at every level to provide opportunities for networking among members interested in different issues in science education and to support the career development of our younger ASCB members.

Committee members are now hard at work, planning/ organizing events for the ASCB Annual Meeting, to be held this year in San Francisco on December 14-18. We want your suggestions and your participation! The Education Poster Session this year will be scheduled for Monday, December 9. Education posters can cover a wide variety of topics, including descriptions of new programs, innovative teaching approaches and laboratory and/or computer-based investigations by students. Work in graduate education, undergraduate education, and $\mathrm{K}-12$ outreach are all appropriate. Remember that all ASCB members can contribute a poster in Education in addition to a poster on laboratory research, and we encourage you to do so.

The Education Committee will continue to sponsor the Education Initiative Forum on Monday-Wednesday from 9:45 to

DOI: $10.1187 /$ cbe.02-04-0011

Corresponding author. E-mail: selgin@biology.wustl.edu.
10:15 am. Each day a different topic is presented and discussed. Presenters include invited speakers and those selected from among the abstracts submitted for the Education Poster Session. On Sunday, this time will be devoted to presentation of the Bruce Alberts Award for Excellence in Science Teaching, with a talk by the awardee. (See the ASCB Newsletter for a recent solicitation of nominations for this award.)

This year we are also planning a return of the Saturday afternoon workshop (scheduled for December 14, 1-5:30 pm), "New Paradigms in Introductory and Cell Biology," centered on the undergraduate curriculum. We anticipate a focus on utilizing interdisciplinary approaches in the introductory curriculum and are particularly interested in examples that provide a mathematics-rich environment for teaching biology. The program will include both presentations by invited speakers and presentations selected from the Education Abstracts. In addition to the platform presentations, time will be provided for break-out discussion groups. We are scouting now for outstanding examples of undergraduate teaching to include; please send your nominations to education@ ascb.org.

Last year, with the guidance of 2001 President Elaine Fuchs, we initiated a luncheon program on K-12 science outreach, "Educating Our Cell Biologists of the Future." The program featured introductory remarks by Bruce Alberts (National Academy of Sciences) and Maxine Singer (Carnegie Institute of Washington), followed by round-table discussions led by a K-12 teacher and an ASCB member who had both participated in a collaborative outreach effort. This event was enthusiastically received, and will be repeated at the 2002 meeting on Sunday, December 15, noon to $2 \mathrm{pm}$. The opening presentation will feature one of the outstanding $\mathrm{K}-12$ science outreach efforts ongoing in the Bay area. As part of this program, the Education Committee produced a booklet providing background material on key resources and ideas for sharing science, listing current outreach programs from all 50 states (see http://ascb.org/ committees/edcom/educating.html). We will be updating the booklet for the 2002 meeting; if you are currently involved in a $\mathrm{K}-12$ outreach program and would like to have this program listed, please send an appropriate program description and contact information to us at education@ascb.org.

The Education Committee will continue to sponsor many other meeting activities, including computer demonstrations and other discussions at the Education/Minority Affairs booth, presentation of the Career Panel, and other events. We are currently reviewing our program, looking in particular at ways to make the annual meeting "user friendly" for undergraduates, graduate students, and postdocs, in addition to our regular stalwart members. Your suggestions and comments are welcome; please send ideas and criticisms to education@ascb.org. 